\title{
Reproduction and Larval Morphology of Broadcasting and Viviparous Species in the Cryptasterina Species Complex
}

\author{
MARIA BYRNE ${ }^{1 *}$, MICHAEL W. HART $^{2}$, ANNA CERRA ${ }^{1}$, AND PAULA CISTERNAS $^{1}$ \\ ${ }^{1}$ Department of Anatomy and Histology, F13, University of Sydney, NSW 2006, Australia; and \\ ${ }^{2}$ Department of Biology, Dalhousie University, Halifax, Nova Scotia B3H 4J1, Canada
}

\begin{abstract}
The Cryptasterina group of asterinid sea stars in Australasia comprises cryptic species with derived life histories. $C$. pentagona and $C$. hystera have planktonic and intragonadal larvae, respectively. $C$. pentagona has the gonochoric, free-spawning mode of reproduction with a planktonic lecithotrophic brachiolaria larva. C. hystera is hermaphroditic with an intragonadal lecithotrophic brachiolaria, and the juveniles emerge through the gonopore. Both species have large lipid-rich buoyant eggs and well-developed brachiolariae. Early juveniles are sustained by maternal nutrients for several weeks while the digestive tract develops. C. hystera was reared in vitro through metamorphosis. Its brachiolariae exhibited the benthic exploration and settlement behavior typical of planktonic larvae, and they attached to the substratum with their brachiolar complex. These behaviors are unlikely to be used in the intragonadal environment. The presence of a buoyant egg and functional brachiolaria larva would not be expected in an intragonadal brooder and indicate the potential for lifehistory reversal to a planktonic existence. Life-history traits of species in the Cryptasterina group are compared with those of other asterinids in the genus Patiriella with viviparous development. Modifications of life-history traits and pathways associated with evolution of viviparity in the Asterinidae are assessed, and the presence of convergent adaptations and clade-specific features associated with this unusual mode of parental care are examined.
\end{abstract}

Received 28 March 2003; accepted 23 July 2003.

* To whom correspondence should be addressed. E-mail: mbyrne@anatomy.usyd.edu.au

\section{Introduction}

Speciation in marine invertebrate taxa is strongly influenced by the evolution of life-history traits. Evolutionary changes that influence speciation include modifications to gamete-binding proteins, oogenesis, larval nutrition (planktotrophic, lecithotrophic), and location (planktonic, benthic) of development (Strathmann, 1985; Reid, 1990; Palumbi, 1992; Vacquier et al., 1995; Byrne et al., 1999, 2003; Duda and Palumbi, 1999; ÓFoighil and Taylor, 2000; Villinski et al., 2002). In a large number of these cases, the combination of rapid and diverse evolution of larval forms and stasis in adult stages has resulted in congeneric species with markedly different larval phenotypes and habitats but similar adult phenotypes and ecologies. This decoupling of larval and adult morphological evolution suggests that critical examination of suspected morphospecies will reveal undiscovered marine biodiversity. Molecular and developmental studies have shown that many problematic taxa include a suite of cryptic species (Reid, 1990; Knowlton, 1993; Degnan and Lavin, 1995; ÓFoighil and Smith, 1995; Arndt et al., 1996; Huber et al., 2000). Application of the comparative approach has made many of these taxa important models for the investigation of processes underlying evolution and development, and speciation in the sea (Hart et al., 1997; Degnan and Lavin, 1995; Huber et al., 2000).

The potential for species divergence through life-history evolution is common in some marine invertebrate taxa but rare in other, even closely related, taxa. Genera in which speciation is associated with evolution of development are found among gastropods (Littorina, Conus), clams (Lasaea), soft corals (Alcyonium), asteroids (Asterina, Patiriella), echinoids (Heliocidaris) and ascidians (Molgula) (Reid, 1990; ÓFoighil and Smith, 1995; Raff, 1996; Hart et 
al., 1997; Duda and Palumbi, 1999; Huber et al., 2000; McFadden et al., 2001). Why some taxa are prone to developmental evolution and not others is not known. In the Asteroidea, the Asterinidae is a species-rich family comprising species that share derived forms of reproduction, larval morphology, and brood protection (Byrne and Cerra, 1996; Byrne et al., 1999b). Molecular phylogenetic analyses of these sea stars revealed many examples of convergence in which derived life-history traits have evolved through independent pathways (Hart et al., 1997, 2003).

In temperate Australia, the Patiriella exigua species group includes three species: one benthic egg layer and two viviparous lineages (Dartnall, 1969, 1971; Keough and Dartnall, 1978). Until the observation of live birth, the viviparous species were considered to be morphs of $P$. exigua. Detailed analysis of mtDNA sequences revealed the presence of a second cryptic group of asterinids in the genus Cryptasterina, which occurs throughout Australasia (Hart et al., 2003; Dartnall et al., 2003). These sea stars, formerly in the Patiriella pseudoexigua species complex (Dartnall, 1971; Rowe and Gates, 1995), have been reassigned to Cryptasterina in a recent taxonomic review (Dartnall et al., 2003). One lineage, C. pentagona, (formerly P. pseudoexigua) occurs in Queensland. A second lineage, Cryptasterina $\mathrm{n}$. sp. (also formerly known as $P$. pseudoexigua) occurs in Wanlitung, Taiwan, and its planktonic lecithotrophic life history is well-documented (Chen and Chen, 1992). The viviparous species described by Hayashi (1977), Patiriella pseudoexigua pacifica, has been reassigned to $C$. pacifica (Dartnall et al., 2003).

On the basis of the position of $C$. pentagona in the phylogenetic tree, nested between broadcasting and brooding species (Hart et al., 1997), and in light of the very broad geographic range of this nominal species, it appeared likely that Australian morphs of $C$. pentagona would have interesting modes of development. A recent molecular study revealed the relationships among four lineages of this taxon recently called $P$. pseudoexigua (Hart et al., 2003). In Queensland these lineages comprise two species with different life histories (Hart et al., 2003). One of these species, C. hystera, is a recently described intragonadal brooder (Dartnall et al., 2003). In this study we examined populations of Cryptasterina from the original type locality in Queensland and elsewhere along the coast to document details of their reproduction and development. We compared the life history traits of $C$. hystera to those of other viviparous asterinids in the genus Patiriella and closely related broadcasting species to assess the changes associated with the evolution of viviparity. This life history is at the extreme end of the broadcast-brooding modes of propagation in the Asteroidea. The pathways in the evolution of viviparity in the Asterinidae are assessed, and the potential for convergent adaptations in species with this unusual mode of parental care is examined.

\section{Materials and Methods}

Cryptasterina pentagona was collected from five locations along the Queensland coast (Fig. 1) at irregular intervals between 1996 and 2002. This included several sites in North Queensland $(10 / 00 ; 11 / 00 ; 10 / 02)$, including Airlie Beach $\left(20^{\circ} 30^{\prime} \mathrm{S} ; 148^{\circ} 45^{\prime} \mathrm{E}\right)$; Rowes Bay, Townsville $\left(19^{\circ} 15^{\prime} \mathrm{S}\right.$; $\left.146^{\circ} 50^{\prime} \mathrm{E}\right)$; and Bingil Bay, Mission Beach $\left(17^{\circ} 50^{\prime} \mathrm{S} ; 146^{\circ} 06^{\prime} \mathrm{E}\right)$. C. hystera was collected from Statue Bay $\left(23^{\circ} 15^{\prime} \mathrm{S} ; 150^{\circ} 45^{\prime} \mathrm{E}\right)$ in central Queensland $(8 / 96 ; 2 / 96$; $9 / 97 ; 10 / 99)$. The samples were used to assess the condition of the gonads and preserve samples for histology. The type locality for $P$. pseudoexigua is Airlie Beach (Dartnall, 1971). In October 2002, the gonads of specimens from Airlie Beach and several sites in Bowen $\left(20^{\circ} 1^{\prime} \mathrm{S}\right.$; $\left.148^{\circ} 16^{\prime} \mathrm{E}\right)$ - Dalrymple Point, Rose Bay, and Murrays Bay (Fig. 1) -were examined and processed for histology. Isolated ovaries of females from these sites and from Rowes Bay, Townsville, were induced to spawn through the use of

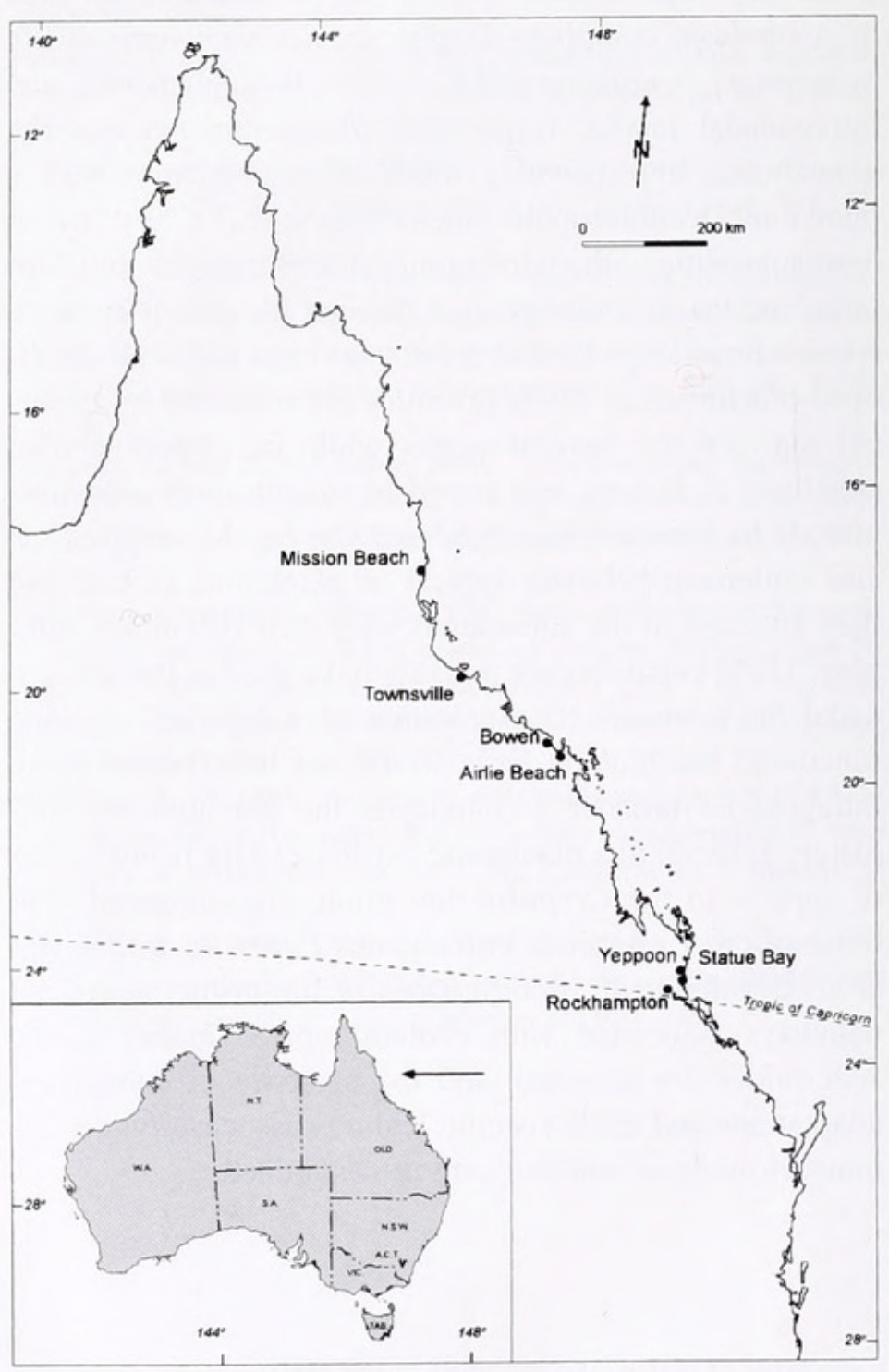

Figure 1. Map of Queensland showing sample locations and current known distributions of Cryptasterina pentagona and C. hystera. 
the ovulatory hormone 1-methyladenine in filtered seawater $\left(10^{-5} M\right.$ in filtered seawater [FSW]). The eggs were fertilized with sperm removed from the testes, and the larvae were reared in FSW at $23-25{ }^{\circ} \mathrm{C}$. Settlement substrata including glass slides aged in seawater and pieces of coralline algae were introduced into some culture dishes containing competent larvae. The gonads of the Statue Bay sea stars contained embryos. These were removed and reared in vitro in FSW $(1.0 \mu \mathrm{m})$ at $22{ }^{\circ} \mathrm{C}$ through metamorphosis.

For histology, the gonads were fixed in Bouin's fluid for $24 \mathrm{~h}$, rinsed in distilled water, dehydrated in graded ethanols, and embedded in paraffin. Serial sections were stained with hematoxylin and eosin. For scanning electron microscopy, larvae and juveniles were fixed for $1 \mathrm{~h}$ in $2.5 \%$ glutaraldehyde in $0.45 \mu \mathrm{m}$ FSW. Use of a secondary fixative was found to be unnecessary (Byrne, pers. obs.). After fixation, the specimens were dehydrated, critical-pointdried, and viewed with a JEOL JSM-35C scanning electron microscope.

\section{Results}

Our field survey of life-history traits in six populations of Cryptasterina provided data on the distribution of two lineages, one broadcasting species and one intragonadal brooder. $C$. pentagona from the type locality Airlie Beach (Fig. 1) was found to be a free-spawner with a short-lived planktonic larva. This species was found from Airlie Beach to Mission Beach in north Queensland (Fig. 1). Mission Beach is near the northern limit of the distribution of $C$. pentagona in Queensland (A.J. Dartnall, James Cook University, pers. comm.). This species was located under rocks high in the intertidal zone which dry out at low tide. Reports of $C$. pentagona south of Airlie Beach will have to be checked in light of the discovery of $C$. hystera in Statue Bay, Central Queensland (Fig. 1). C. hystera is an intragonadal brooder. Molecular data indicate that this new species also occurs in Yeppoon (Hart et al., 1997). It occurs high in the intertidal under small rocks in mangrove habitats. The distribution of the two species may overlap south of Airlie Beach. A thorough search of the sites used in this study indicated that the two species do not co-occur in north Queensland.

\section{Planktonic developer}

C. pentagona is a dioecious free-spawner with a planktonic lecithotrophic brachiolaria larva (Figs. 2A, B, D; 3AC). Ovaries of specimens collected in October and November 2000 and October 2002 were gravid (Fig. 2A). They contained large eggs dominated by large lipid droplets. Spawned eggs (413 $\mu \mathrm{m}$ diameter; $\mathrm{SE}=6.4 \mu \mathrm{m}, n=20$ ) were an amber-gold color. They were positively buoyant and floated to the surface as they emerged from the gonopore. Mature testes were typical of asteroids, having a layer of spermatogenic columns along the germinal epithelium and a lumen filled with sperm (Fig. 2B).

Development of $C$. pentagona through the stages of holoblastic radial cleavage, early blastula, wrinkled blastula, and gastrula was typical of development in lecithotrophic sea stars (Byrne, 1995). At $23{ }^{\circ} \mathrm{C}$ the early larvae ( 2 days) had a large preoral lobe and developing larval arms (brachia) (Fig. 3A). The central brachium developed as a bulge that emerged from the preoral lobe, flanked posteriorly on either side by two lateral brachia (Figs. 2D, 3B). Advanced brachiolariae ( 5 days) had a prominent brachiolar complex comprising three brachia and a central adhesive disc (Fig. 3C). Early larvae swam at the surface propelled by their cover of cilia (Fig. 3A, B, F); but as the juvenile rudiment developed in the posterior region, they swam at the bottom of the culture dishes, anterior end up. An extracellular matrix with meshlike holes covered the surface of the larvae and juveniles (Fig. 3F). This feature was most evident over the brachia of the larvae and on the oral surface and tube feet of the juveniles. Advanced larvae adhered to surfaces using their brachia. As they explored the substratum, they flexed dorsally to bring the adhesive disc to the surface. Once they were committed to metamorphose, permanent benthic attachment was achieved by the adhesive disc assisted by the brachia. The larvae attached to a range of substrata including the walls of the culture dishes, although they appeared to favor coralline algae (Fig. 2F). Most larvae metamorphosed regardless of whether a specific settlement substratum was introduced into the culture dishes. Many of them settled on the walls of their containers. Newly metamorphosed juveniles $(620 \mu \mathrm{m}$ diameter; $\mathrm{SE}=11.8, n=$ 15) had two pairs of tube feet in each radius (Fig. 3D, E). They were a dark amber color, indicating the presence of extensive maternal nutritive reserves. The mouth did not open for 3 weeks after settlement (Fig. 3D). Development to the settled juvenile stage took 9 days at $23{ }^{\circ} \mathrm{C}$, while at ambient temperatures $\left(30^{\circ} \mathrm{C}\right)$ in Queensland, development was completed in 6 days (Dartnall, pers. comm.).

\section{Intragonadal developer}

C. hystera had ovotestes that were a mosaic of oogenic and spermatogenic areas (Fig. 2C). Gravid specimens were present in all the samples obtained from September to November, indicating that the reproductive period lasts at least 3 months. In December 1999, the gonads contained juveniles and few gametes. The amount of spermatogenic tissue in the gonads varied among individuals $(n=20)$. In some specimens, sperm was only detectable histologically; in others, white testicular regions of the gonad were evident by direct examination. Like those of $C$. pentagona, the eggs were large (440 $\mu \mathrm{m}$ diameter; $\mathrm{SE}=6.0 \mu \mathrm{m}, n=8)$ and contained abundant lipid droplets. They floated to the sur- 

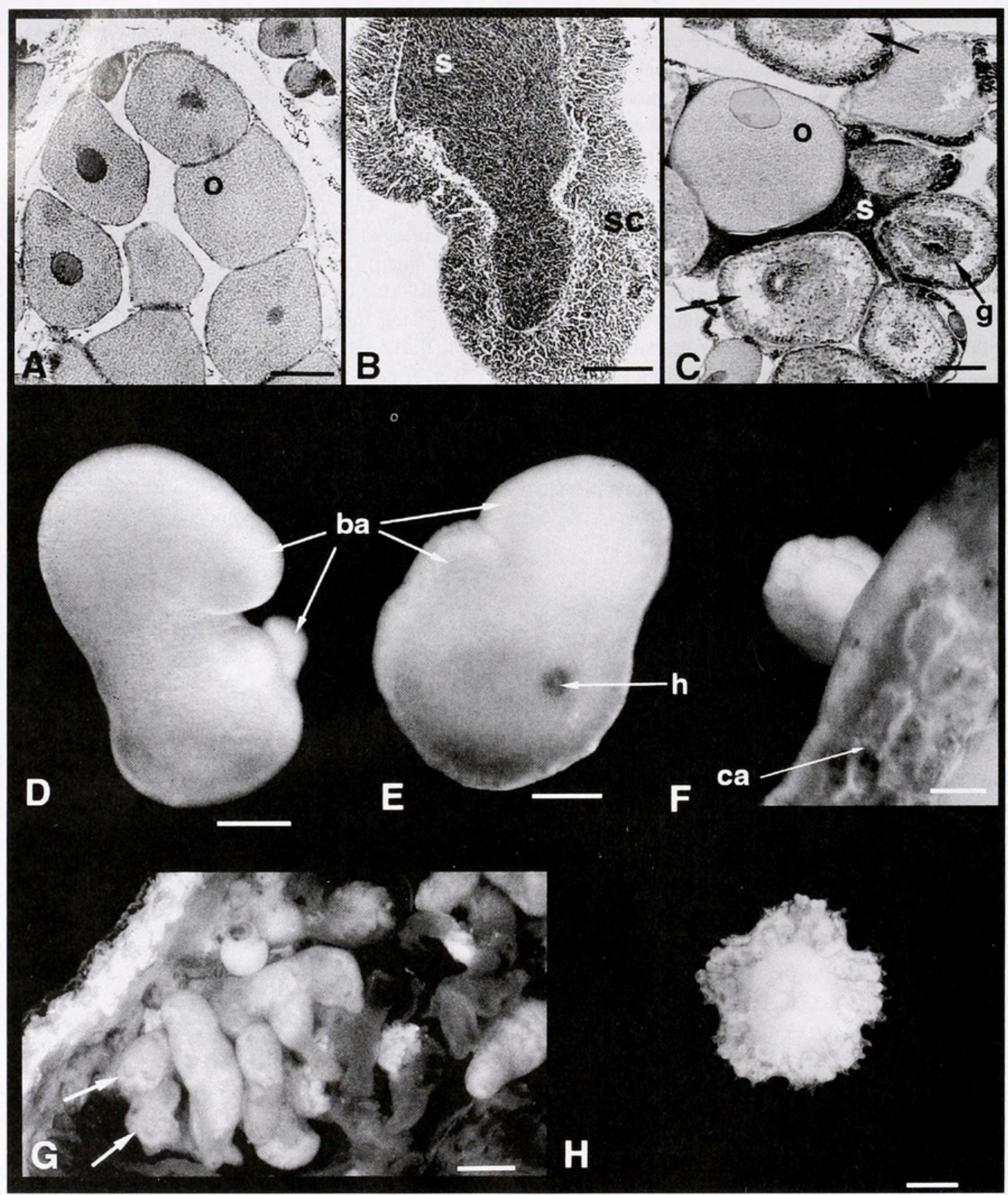

Figure 2. Histology and light microscopy. (A, B) Cryptasterina pentagona ovaries and testes, o, oocyte; s. spermatozoa; sc, spermatocyte columns. (C) C. hystera. The ovotestis contains lipid-rich eggs (o), sperm (s), and developing embryos (arrows); g, gastrula. (D, E) Brachiolaria larvae of $C$. pentagona and $C$. hystera respectively. ba, brachia; h, hydropore. (F) Metamorphosing juvenile $C$. pentagona on coralline algae (ca). (G) Dissected $C$. hystera showing juveniles (arrows) in gonad. (H) Newly released $C$. hystera. Scales: $\mathrm{A}-\mathrm{E}=100 \mu \mathrm{m} ; \mathrm{F}, \mathrm{H}=$ $200 \mu \mathrm{m} ; \mathrm{G}=500 \mu \mathrm{m}$.

face when removed from the gonad and were gold-orange, with a dark vegetal pole.

Developing embryos and larvae were interspersed with gametes in the gonad (Fig. 2C, G). Embryos removed from the gonad at the early blastula stage developed independently of the parent through the wrinkled blastula and gastrula stages into a planktonic highly buoyant brachiolaria. The developing brachia appeared as three bulges (Fig. 

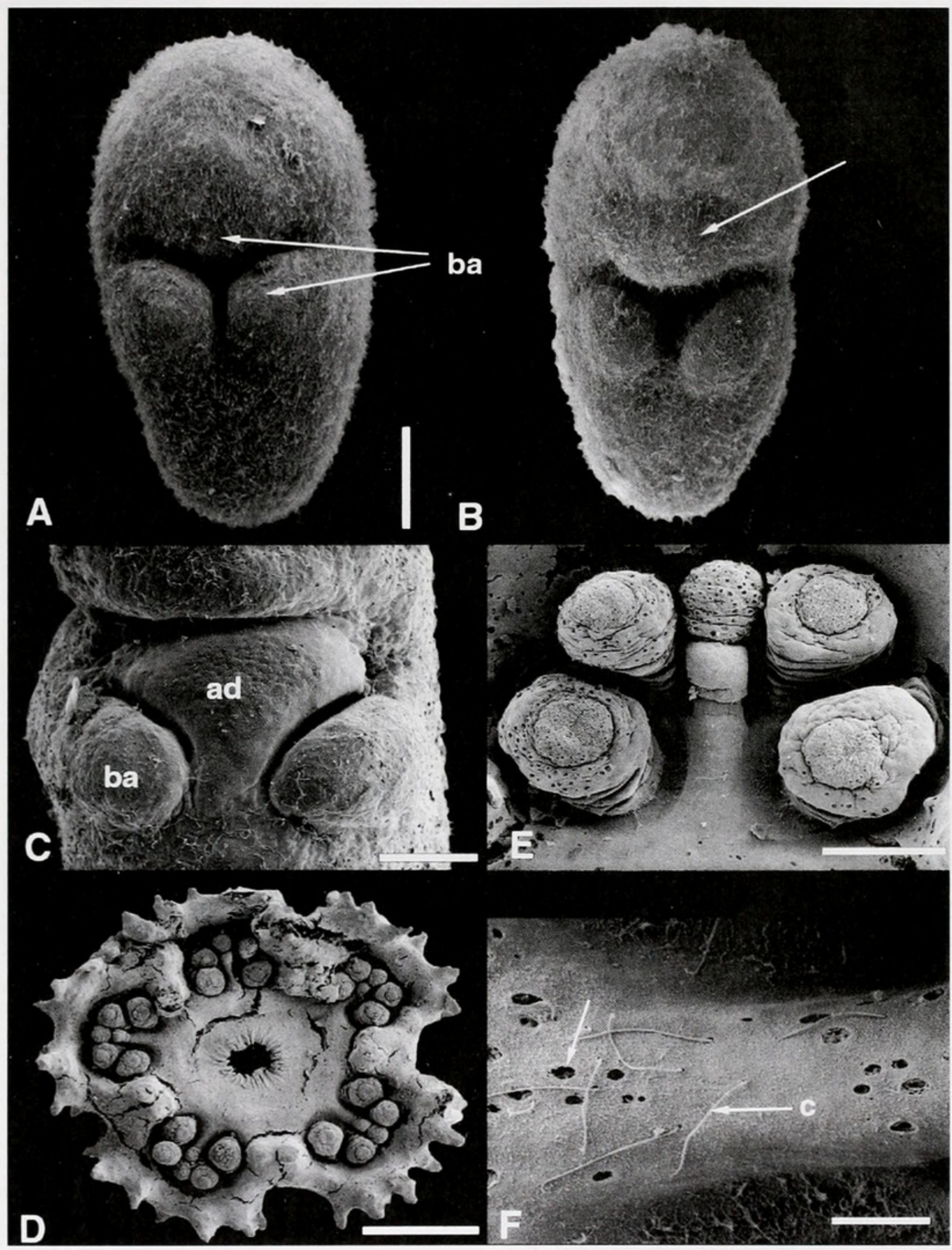

Figure 3. Scanning electron microscopy, Cryptasterina pentagona. (A, B) Brachiolaria larvae have a uniform cover of cilia. The central brachium (arrow) develops as a protrusion of the preoral lobe. (C) Advanced larva with a well-developed adhesive disc (ad) at the base of the brachia (ba). (D, E) Recently metamorphosed juvenile with two pairs of tube feet in each radius and with a mouth opening. (F) Detail of cilia (c) and meshlike matrix on larval surface. Scales: $A, B=100 \mu \mathrm{m} ; \mathrm{C}, \mathrm{E}=50 \mu \mathrm{m} ; \mathrm{F}=4 \mu \mathrm{m}$.

4A), and the adhesive disc developed between the arms (not illustrated). As in $C$. pentagona, advanced larvae had a well-developed preoral lobe from which the central brachium emerged as a bulge-like protrusion (Fig. 4B, C). They swam anterior end up with their ciliary cover (Fig. 4F). Advanced larvae (10 days) had a well-developed brachiolar complex which was used for benthic attachment. They exhibited typical settlement behavior while exploring the 

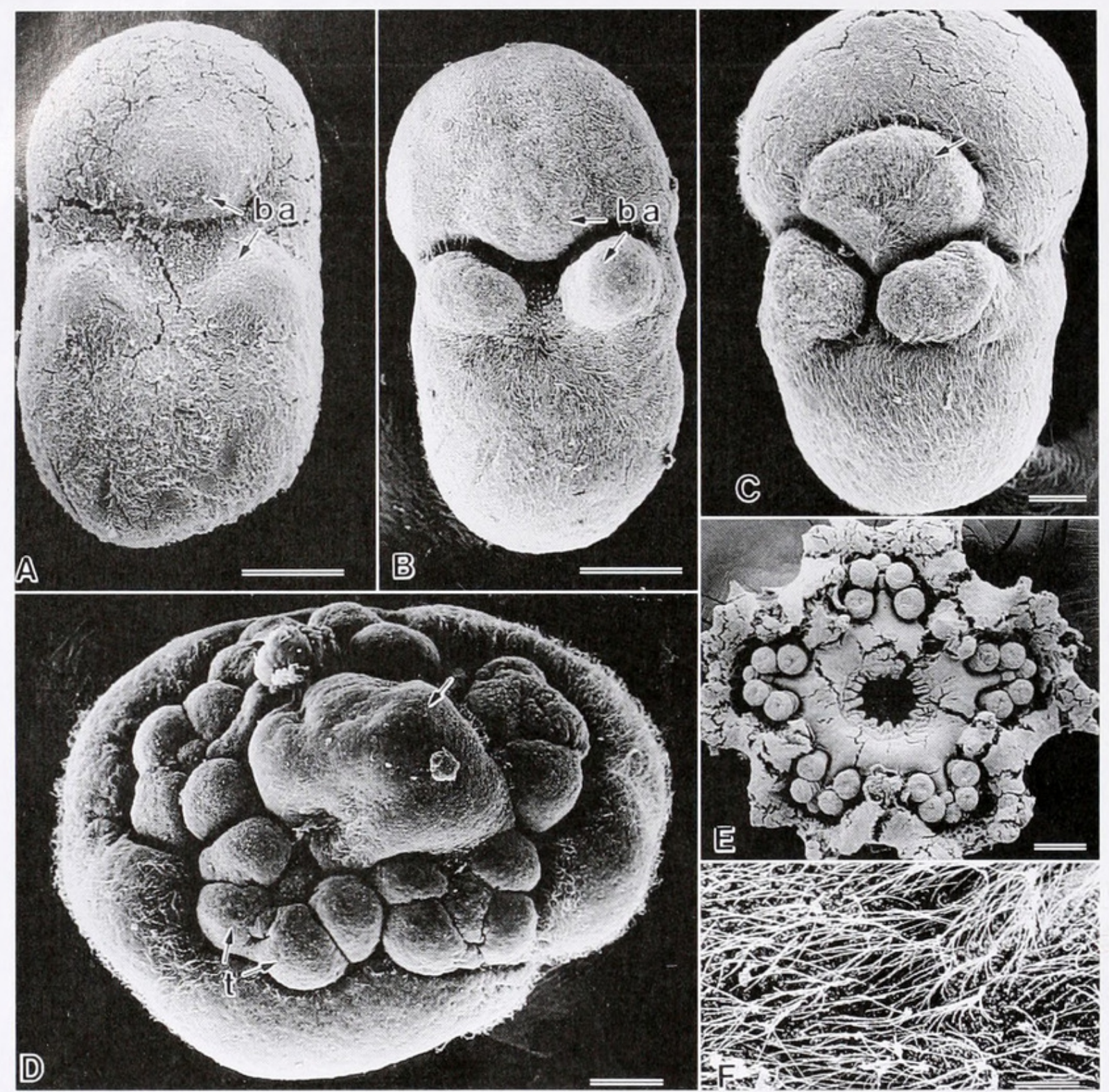

Figure 4. Scanning electron microscopy, Cryptasterina hystera. (A, B) Early larvae with developing brachia (ba). (C) Advanced larva. The central brachium (arrow) develops as a posterior protrusion of the preoral lobe. (D) Metamorphosing larva with resorbing larval body (arrow) and developing tube feet (t). (E) Recently metamorphosed juvenile with two pairs of podia in each radius and with a mouth opening. (F) Detail of cilia on larval surface. Scales: A, B, E $=100 \mu \mathrm{m} ; \mathrm{C}, \mathrm{D}=50 \mu \mathrm{m} ; \mathrm{F}=12 \mu \mathrm{m}$.

substratum and adhered to the surface of the culture dishes either with the tips of the brachia or by flexing the body to attach the adhesive disc. The juvenile rudiment developed in the posterior region as the larval body was resorbed (Fig. $4 \mathrm{D})$. Development in vitro to the juvenile stage took 16 days. Newly settled juveniles had a dark amber pigment due to the presence of maternal nutritive reserves. It took 3 weeks for the mouth opening to develop, and by this time maternal reserves were no longer evident (Fig. 4E). Threeweek-old juveniles had a well-developed skeleton.

In aquaria, jüveniles ( $800 \mu \mathrm{m}$ diameter, $\mathrm{SE}=6.3, n=$ $10)$ with two pairs of tube feet in each radius emerged from the gonopore on the aboral surface of the adults (Fig. 2H). These juveniles had a mouth opening, a functional digestive tract, and a well-developed skeleton. Newly released juveniles were white due to the color of the skeleton, and they appeared to lack residual maternal nutrients.

\section{Discussion}

Recent discoveries of cryptic species in a range of taxa have been facilitated by investigation of developmental evolution and molecular phylogeny (Reid, 1990; Degnan and Lavin, 1995; ÓFoighil and Smith, 1995; Williams, 2000; Flowers and Foltz, 2001; McFadden et al., 2001). Observations of juvenile birth resulted in the description of new viviparous Patiriella in the P. exigua group (Dartnall, 1969, 1971; Keough and Dartnall, 1978), and our investi- 
gation of cryptic biodiversity in Cryptasterina was prompted by the results of molecular phylogeny (Hart et al., 1997). The Asterinidae are a taxonomically difficult group and detection of the cryptic species investigated here would have been difficult with traditional taxonomy because adult forms appear very similar even to taxonomic experts (Dartnall, 1971; Rowe and Gates, 1995). Once specific status has been determined, however, close examination of cryptic species may reveal the presence of diagnostic morphological traits (Dartnall, pers. comm.). Indeed, life-history and molecular data have guided taxonomic effort in the discovery and description of several cryptic Patiriella species in New Zealand and Australia (O'Loughlin et al., 2002; Dartnall, pers. comm.). Molecular data revealed that $C$. pentagona, the broadcasting species, occurs from the type locality Airlie Beach north to Townsville (Fig. 5; Hart et al., 2003). C. hystera is known only from two locations, about $10 \mathrm{~km}$ apart. An extremely limited distribution is also characteristic of the viviparous Patiriella (Byrne et al., 1999b). A survey of mangrove habitats along the central Queensland coast will be required to determine the distribution of $C$. hystera. The nominal taxon $C$. pentagona occurs through Asia (Marsh, 1977; VandenSpiegel et al., 1998), and it is likely that other divergent lineages will be found (Dartnall et al., 2003). Other widely distributed asterinids such as Patiriella exigua, which occurs from South Africa to Australia, also appear to be a suite of cryptic species (Dartnall, pers. comm.).

The life-history traits and phylogenetic relationships of species in the Cryptasterina pentagona group and the $\mathrm{Pa}$ tiriella exigua group are shown in Table 1 and Figure 5. The gonochoric, free-spawning mode of reproduction seen in $C$. pentagona and Cryptasterina $\mathrm{n}$. sp. is ancestral for the Echinodermata, while acquisition of hermaphroditism, a derived character, is exhibited by most echinoderms that brood their young (Strathmann et al., 1984; Byrne, 1991, 1999; Hendler, 1991). Like those of the other viviparous species (Table 1), the gonads of $C$. hystera were ovotestes. This indicates the potential for self-fertilization, as appears to be the case for $P$. vivipara (Byrne, 1996). The amount of sperm in the gonads of $C$. hystera is more than sufficient to fertilize all the eggs produced, and so it is likely that some individuals release sperm. For out-crossing to occur, the sperm would have to gain access to eggs by swimming through the gonopore. A genetic study is required to determine if progeny in the gonads of the viviparous Cryptasterina and Patiriella are full siblings or half siblings. The diversity of the fertilization biology in these asterinids with complete out-crossing in the free-spawners, partial selffertilization in the benthic egg layers, and potential for selfing in viviparous forms provides a useful model in which to investigate the relationships between the evolution of mating systems and the genetic structure of sea star populations (Byrne, 1995, 1996).

As characteristic of echinoderms, the evolution of lecithotrophy in Cryptasterina species involved acquisition of a large egg (Table 1). The increase in egg size from what would have been an ancestral form with a small egg and planktotrophic development is considered to have been necessary to sustain development without feeding (Mortensen, 1921; Strathmann, 1978; Emlet et al., 1987). The presence of extensive nutritive reserves in newly metamorphosed juveniles, however, shows that a considerable portion of maternal reserves in the eggs of the two Cryptasterina species investigated here is allocated to the perimetamorphic postlarval period. A substantial proportion of the maternal provisions in their large eggs is stored through larval development to support development of the postlarval stages, a feature seen in other lecithotrophic echinoderms (Emlet and Hoegh-Guldberg, 1997; Hoegh-Guldberg and Emlet, 1997; Byrne et al., 1999a, 2003; Villinski et al., 2002). In contrast, the small eggs (135-150 $\mu \mathrm{m}$ diameter) of $P$. vivipara and $P$. parvivipara are similar in size to those (150 $\mu \mathrm{m}$ diameter) of their planktotrophic congener $P$.

Table 1

Life-history traits of the Cryptasterina pentagona and Patiriella exigua species groups

\begin{tabular}{|c|c|c|c|c|}
\hline Species* & Location $\div$ & Gonad structure & Egg size (diam in $\mu \mathrm{m}$ ) & Larval habitat \\
\hline \multicolumn{5}{|l|}{ C. pentagona group } \\
\hline C. pentagona & Qld & Dioecious & 413 & Planktonic \\
\hline C. hystera & Qld & Hermaphrodite & 440 & Intragonadal \\
\hline C. pacifica (1) & Japan & Hermaphrodite & 450 & Intragonadal \\
\hline C. n. sp. (2) & Taiwan & Dioecious & 320 & Planktonic \\
\hline \multicolumn{5}{|l|}{ P. exigua group } \\
\hline P. exigua $(3)$ & NSW, Tas, SA & Dioecious & 360 & Benthic \\
\hline P. vivipara (4) & Tas & Hermaphrodite & 150 & Intragonadal \\
\hline P. parvivipara (4) & SA & Hermaphrodite & 135 & Intragonadal \\
\hline
\end{tabular}

* (1) Komatsu et al. (1990); (2) Chen and Chen (1992); (3) Byrne (1995); (4) Byrne (1996).

$\doteqdot$ NSW, New South Wales; Qld, Queensland; SA, South Australia; Tas, Tasmania. 


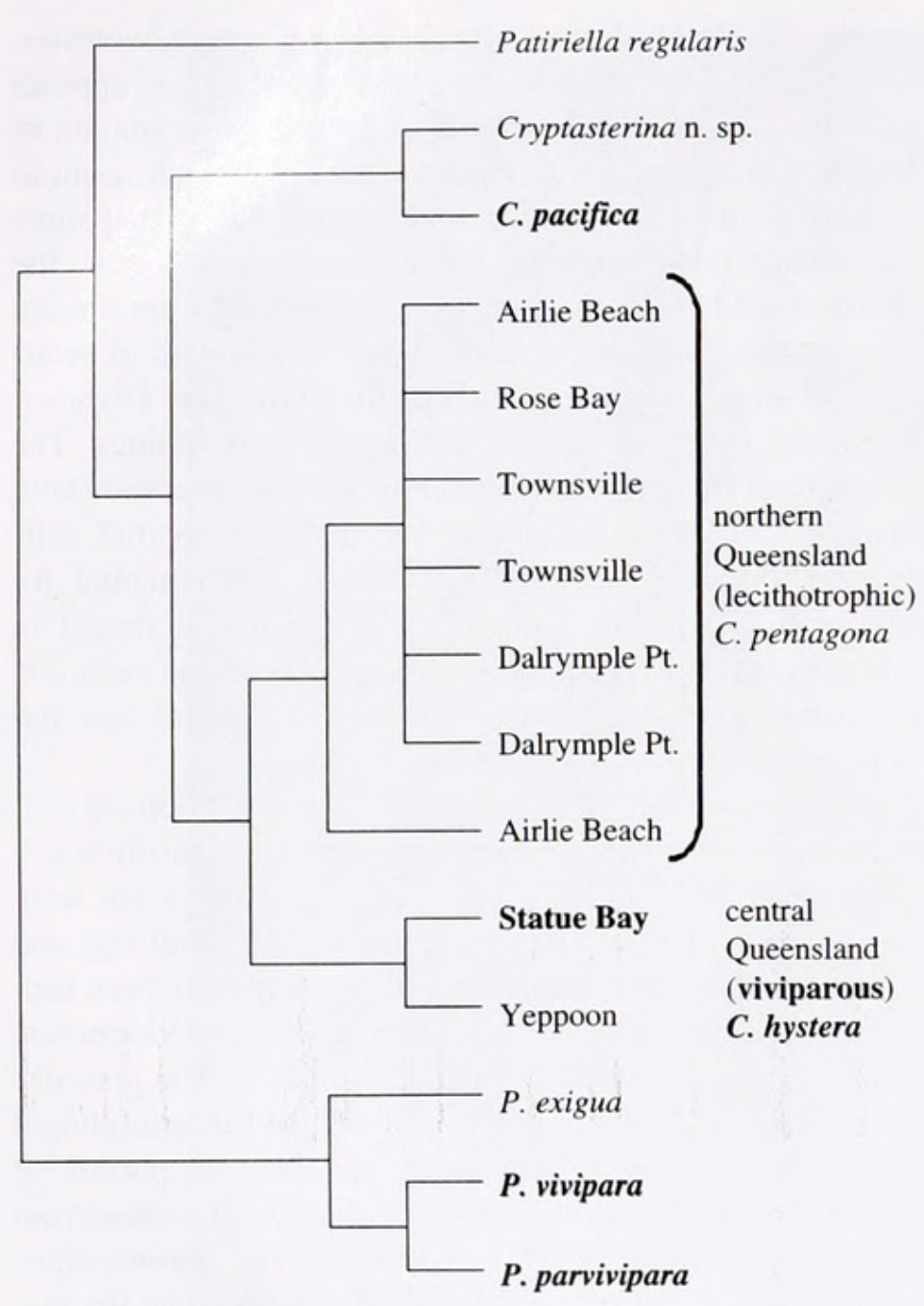

Figure 5. Phylogenetic tree based on branch-and-branch searching of mtDNA sequences (COI and 5 tRNA genes) from the Cryptasterina pentagona and Patiriella exigua groups (after Hart et al., 1997, 2003). Species in bold are known to be viviparous. Bootstrapping produced strong support ( $\geq 92 \%$ ) for monophyly of the six northern Queensland lineages, for two southern Queensland lineages, and for all these lineages as a clade separate from $P$. regularis. The Yeppoon specimen was from a museum collection and the presence of intragonadal embryos could not be confirmed.

regularis and represent a secondary reduction in size (Byrne and Cerra, 1996; Hart et al., 1997). The eggs of $P$. vivipara and $P$. parvivipara support intragonadal lecithotrophic development to a very small postlarva (200-300 $\mu \mathrm{m}$ diameter), indicating that the maternal reserves in these eggs may be near the limit required to support development through metamorphosis in the absence of feeding (Byrne, 1996).

The larvae and juveniles of $C$. pentagona have a meshlike extracellular matrix covering regions of the body, similar to that described for P. regularis (Byrne and Barker, 1991). Preservation of this matrix depends on fixation method, suggesting it may be an artifact (Byrne, pers. obs.). Alternatively, its presence in some regions of larvae and juveniles such as the brachiolar arms and oral surface indicates that the extracellular matrix may have regional differences.

Newly settled juveniles of $C$. pentagona $(612 \mu \mathrm{m}$ diam- eter) and $C$. hystera (600 $\mu \mathrm{m}$ diameter) reared in vitro were supported by maternal nutrients for several weeks until the digestive tract became functional and juveniles could feed. Juveniles of $C$. hystera (2-3 weeks old, $800 \mu \mathrm{m}$ diameter) left the parent with a functional gut. Similarly, newly metamorphosed juveniles of $C$. pacifica $(650 \mu \mathrm{m}$ diameter) emerge from the gonopore ( $900 \mu \mathrm{m}$ diameter) with a functional gut (Komatsu et al., 1990). The juveniles of $P$. vivipara and $P$. parvivipara continue their growth in the gonads to become the largest recruiting juveniles (1.0-5.0 mm diameter) known for the Asteroidea (Byrne, 1996). They spend up to a year in the gonads preying on their siblings, an unconventional source of maternal nutrients. There may be selection for extended brood care in the viviparous species. Intragonadal brooding of progeny through the vulnerable early postlarval stages and their release at a large size undoubtedly conveys a survival advantage for the juveniles. Mortality of the early settlement stages of marine invertebrates is usually high (Gosselin and Qian, 1997). Interestingly, the gonads of $C$. hystera contained a few large juveniles (1-2 mm diameter), indicating that brood cannibalism occasionally occurs in this species (Byrne, pers. obs.).

The eggs of species in the Cryptasterina group have conspicuous lipid reserves, a feature characteristic of echinoderms with planktonic lecithotrophy (Emlet et al., 1987; Emlet and Hoegh-Guldberg, 1997; Hoegh-Guldberg and Emlet, 1997; Byrne et al., 1999a, 2003; Villinski et al., 2002). Their brachiolariae are also similar in appearance, with a prominent preoral lobe and a central brachium that develops as a bulge-like protrusion (Komatsu et al., 1990). Possession of a buoyant egg and a functional larva in $C$. hystera and $C$. pacifica would not be expected in viviparous asteroids. These features and the morphological similarity of their larvae to those of congeners with planktonic development suggest that viviparity in these sea stars evolved through retention and fertilization of a large egg by a $C$. pentagona-like ancestor. This suggestion is supported by molecular phylogenetic data (Fig. 5; Hart et al., 2003).

The intragonadal brachiolariae of $P$. vivipara and $P$. parvivipara are vestigial, unlike those of $C$. hystera. Their minute larvae have a reduced brachiolar complex comprising three small nonsticky protrusions that cannot function in attachment, and some embryos do not develop brachia at all. Intragonadal development in $P$. vivipara and $P$. parvivipara is thought to have evolved through a $P$. exigua-like ancestor that laid benthic egg masses and had highly modified benthic nondispersive larvae (Fig. 5; Byrne, 1995; Hart et al., 1997). Evolution of viviparity through retention of eggs by an ancestor with benthic egg masses is suggested to have been a likely pathway for the acquisition of this form of brooding in asterinids (Strathmann et al., 1984; Byrne, 1996).

Despite their intragonadal location, the larvae of $C$. hys- 
tera exhibited exploratory settlement behavior and attached to the substratum with their brachia and adhesive disc prior to metamorphosis, in a manner typical of planktonic asteroid larvae. This behavior is unlikely to serve any function in the intragonadal environment. A reversal to a planktonic larva is readily envisaged for $C$. hystera and $C$. pacifica, a suggestion also made for Pteraster tesselatus (McEdward, 1992). These species could potentially use two modes of development, releasing some progeny as dispersive larvae and others as juveniles. By contrast, $P$. vivipara and $P$. parvivipara are committed to intragonadal development. A reversal to reacquire a large egg and functional larva appears unlikely for $P$. vivipara and $P$. parvivipara.

Intragonadal development is rare in the Echinodermata. Among asteroids, intragonadal development and live birth is known for only three genera, Cryptasterina, Patiriella (Table 1), and the aberrant Xyloplax medusiformis from the deep sea (Rowe et al., 1987). Morphological and molecular evidence supports the conclusion that viviparity evolved independently three times in Patiriella and Cryptasterina (Fig. 5; Hart et al., 1997, 2003). Parallel evolution of derived lecithotrophic life histories is common in echinoderms and is often associated with a suite of convergent phenotypes (Strathmann, 1985; Emlet et al., 1987; Wray, 1996; Hart et al., 1997). For asterinids, some convergent adaptations associated with viviparity are evident in all brooding species, while other features follow phylogenetic lines (Table 1, Fig. 5). With respect to adult traits, convergence is seen in possession of ovotestes and the potential for self-fertilization in both Cryptasterina and Patiriella. Egg type and composition, however, is similar within these genera, but not between them. With respect to developmental phenotype, Cryptasterina and Patiriella differ in the presence of functional or nonfunctional larvae. Regardless of the pathways involved in evolution of viviparity, however, the probability of making the evolutionary switch to intragonadal development appears high in the Asterinidae. Selection for viviparity may be associated with colonization of marginal habitats along the upper fringe of the intertidal, a habitat not generally utilized by sea stars. Why this unusual form of parental care evolved in Cryptasterina and Patiriella and not in other asteroid taxa is not known.

\section{Acknowledgments}

Special thanks to Drs. S. McKillup and J. Collins for providing specimens. The research was supported by a grant from the ARC (MB) and a grant from NSERC (MH).

\section{Literature Cited}

Arndt, A., C. Marquez, P. Lambert, and M. J. Smith. 1996. Molecular phylogeny of eastern Pacific sea cucumbers (Echinodermata: Holothuroidea) based on mitochondrial DNA sequence. Mol. Phylogenet. Evol. 6: $425-437$.
Byrne, M. 1991. Reproduction, development and population biology of the Caribbean ophiuroid Ophionereis olivacea, a protandric hermaprodite that broods its young. Mar. Biol. 111: 387-399.

Byrne, M. 1995. Changes in larval morphology in the evolution of benthic development by Patiriella exigua (Asteroidea: Asterinidae), a comparison with the larvae of Patiriella species with planktonic development. Biol. Bull. 188: 293-305.

Byrne, M. 1996. Viviparity and intragonadal cannibalism in the diminutive asterinid sea stars Patiriella vivipara and $P$. parvivipara. Mar. Biol. 125: 551-567

Byrne, M. 1999. Echinodermata. Pp. 940-954 in Encyclopedia of Reproduction. E. Knobil and J. Neill, eds. Academic Press, New York.

Byrne, M., and M. F. Barker. 1991. Embryogenesis and larval development of the asteroid Patiriella regularis viewed by light and scanning electron microscopy. Biol. Bull. 180: 332-345.

Byrne, M., and A. Cerra. 1996. Evolution of intragonadal development in the diminutive asterinid sea stars Patiriella vivipara and $P$. parvivipara with an overview of development in the Asterinidae. Biol. Bull. 191: 17-26.

Byrne, M., A. Cerra, and J. T. Villinski. 1999a. Oogenic strategies in the evolution of development in Patiriella (Asteroidea). Invertebr. Reprod. Dev. 36: 195-202.

Byrne, M., A. Cerra, M. W. Hart, and M. J. Smith. 1999b. Life history diversity and molecular phylogeny in the Australian sea star genus Patiriella. Pp. 186-196 in The Other 99\%: The Conservation and Biodiversity of Invertebrates, W. Ponder and D. Lunney, eds. Transactions of the Royal Society of New South Wales, Sydney.

Byrne, M., P. Cisternas, P. Selvakumaraswamy, J. T. Villinski, and R. R. Raff. 2003. Evolution of maternal provisioning in ophiuroids, asteroids and echinoids. Pp. 171-175 in Echinoderm Research 2001, J. P. Feral and B. David, eds. Balkema, Lisse, The Netherlands.

Chen, B. Y., and C.-P. Chen. 1992. Reproductive cycle, larval development, juvenile growth and population dynamics of Patiriella pseudoexigua (Echinodermata, Asteroidea) in Taiwan. Mar. Biol. 113: 271280.

Clark, A. M. 1993. An index of names of Recent Asteroidea. Part 2: Valvatida. Pp. 187-366 in Echinoderm Studies, M. J. Jangoux and J. M. Lawrence, eds. Balkema, Rotterdam.

Dartnall, A. J. 1969. A viviparous species of Patiriella (Asteroidea, Asterinidae) from Tasmania. Proc. Linn. Soc. N.S.W. 93: 294-296.

Dartnall, A. J. 1971. Australian sea stars of the genus Patiriella (Asteroidea, Asterinidae). Proc. Linn. Soc. N.S.W. 96: 39-51.

Dartnall, A. J., M. Byrne, J. Collins, and M. W. Hart. 2003 A new viviparous species of asterinid (Echinodermata, Asteroidea, Asterinidae) and a new genus to accommodate the species of pan-tropical exiguoid sea stars. Zootaxa 359:1-14.

Degnan, B. M., and M. F. Lavin. 1995. Highly repetitive DNA sequences provide evidence for a lack of gene flow between two morphological forms of Herdmania momus (Ascidiacea: Stolidobranchia). Mar. Biol. 124: 293-299.

Duda, T. F., and S. R. Palumbi. 1999. Developmental shifts and species selection in gastropods. Proc. Natl. Acad. Sci. USA 96: 10272-10277.

Emlet, R. B., and O. Hoegh-Guldberg. 1997. The effects of egg size on post-larval performance: experimental evidence from a sea urchin. Evolution 51: 141-152.

Emlet, R. B., L. R. McEdward, and R. R. Strathmann. 1987. Echinoderm larval ecology viewed from the egg. Pp. 55-136 in Echinoderm Studies, M. J. Jangoux and J. M. Lawrence, eds. Balkema, Rotterdam.

Flowers, J. M., and D. W. Foltz. 2001. Reconciling molecular systematics and traditional taxonomy in a species-rich clade of sea stars (Leptasterias subgenus Hexasterias). Mar. Biol. 139: 475-483.

Gosselin, L. A., and P. Y. Qian. 1997. Juvenile mortality in benthic marine invertebrates. Mar. Ecol. Prog. Ser. 146: 265-282.

Hart, M. W., M. Byrne, and M. J. Smith. 1997. Molecular phyloge- 
netic analysis of life-history evolution in asterinid starfish. Evolution 51: $1846-1859$

Hart, M. W., M. Byrne, and S. L. Johnson. 2003. Cryptic species and modes of development in Patiriella pseudoexigua. J. Mar. Biol. Assoc. UK 83: 1109-1116.

Hayashi, R. 1977. A new sea-star of Asterina from Japan, Asterina pseudoexigua pacifica n. sp. Proc. Jpn. Soc. Syst. Zool. 13: 88-91.

Hendler, G. 1991. Echinodermata: Ophiuroidea. Pp. 356-511 in Reproduction of Marine Invertebrates. Vol. VI: Echinoderms and Lophophorates. A. C. Giese, J. S. Pearse, and V. B. Pearse, eds. Boxwood Press, Pacific Grove, CA.

Hoegh-Guldberg, O., and R. B. Emlet. 1997. Energy use during the development of a lecithotrophic and planktotrophic echinoid. Biol. Bull. 192: 27-40.

Huber, J. L., K. Burke da Silva, W. R. Bates, and B. J. Swalla. 2000. The evolution of anural larvae in molgulid ascidians. Semin. Cell Dev. Biol. 11: 419-426.

Keough, M. J., and A. J. Dartnall. 1978. A new species of viviparous asterinid asteroid from Eyre Peninsula, South Australia. Rec. S. Aust. Mus. 17: 407-416.

Knowlton, N. 1993. Sibling species in the sea. Annu. Rev. Ecol. Syst. 24: $189-216$.

Komatsu, M., Y. T. Kano, and C. Oguro. 1990. Development of a true ovoviviparous sea star, Asterina pseudoexigua pacifica Hayashi. Biol. Bull. 179: 254-263.

Marsh, L. M. 1977. Coral reef asteroids of Palau, Caroline Islands. Micronesica 13: 251-281.

McEdward, L. R. 1992. Morphology and development of a unique type of pelagic larva in the starfish Pteraster tesselatus (Echinodermata: Asteroidea). Biol. Bull. 182: 177-187.

McFadden, C. S., R. Donahue, B. K. Hadland, and R. Weston. 2001. A molecular phylogenetic analysis of reproductive trait evolution in the soft coral genus Alcyonium. Evolution 55: 54-67.

Mortensen, T. 1921. Studies of the Development and Larval Forms of Echinoderms. G.E.C. Gad, Copenhagen. 261 pp.

OFoighil, D., and M. J. Smith. 1995. Evolution of asexuality in the cosmopolitan marine clam Lasaea. Evolution 49: 140-150.

ÓFoighil, D., and D. J. Taylor. 2000. Evolution of parental care and ovulation behavior in oysters. Mol. Phvlogenet. Evol. 15: 301-313.
O'Loughlin, P. M., J. M. Waters, and M. S. Roy. 2002. Description of a new species of Patiriella from New Zealand and review of Patirella regularis (Echinodermata, Asteroidea) based on morphological and molecular data. J. R. Soc. NZ 32: 697-711.

Palumbi, S. R. 1992. Marine speciation on a small planet. Trends Ecol. Evol. 7: 114-118.

Raff, R. A. 1996. The Shape of Life. University of Chicago Press, Chicago.

Reid, D. G. 1990. A cladistic phylogeny of the genus Littorina (Gastropoda): implications for evolution or reproductive strategies and for classification. Hydrobiologia 193: 1-19.

Rowe, F. W. E., and J. Gates. 1995. Echinodermata. In Zoological Catalogue of Australia, Vol. 33, A. Wells, ed. CSIRO, Melbourne

Rowe, F. W. E., A. N. Baker, and H. E. S. Clark. 1987. The morphology, development and taxonomic status of Xyloplax Baker, Rowe and Clark (1986) (Echinodermata: Concentricycloidea), with the description of a new species. Proc. R. Soc. Lond. B. 233: 431-459.

Strathmann, R. R. 1978. The evolution and loss of feeding larval stages of marine invertebrates. Evolution 32: 894-906.

Strathmann, R. R. 1985. Feeding and nonfeeding larval development and life history evolution in marine invertebrates. Annu. Rev. Ecol. Syst. 16: 339-361.

Strathmann, R. R., M. F. Strathmann, and R. H. Emson. 1984. Does limited brood capacity link adult size, brooding and simultaneous hermaphroditism? A test with the starfish Asterina phylactica. Am. Nat. 123: $796-818$.

Vacquier, V. D., W. J. Swanson, and M. E. Hellberg. 1995. What have we learned about sea urchin bindin? Develop. Growth Differ. 37: 1-10.

VandenSpiegel, D., D. J. W. Lane, S. Stampanato, and M. Jangoux. 1998. The asteroid fauna (Echinodermata) of Singapore with a distribution table and an illustrated identification to the species. Raffles Bull. Zool. 46: 431-470.

Villinski, J. T., J. L. Villinski, M. Byrne, and R. R. Raff. 2002. Convergent maternal provisioning and life history evolution in echinoderms. Evolution 56: 1764-1775.

Williams, S. T. 2000. Species boundaries in the starfish genus Linckia. Mar. Biol. 136: 137-148.

Wray, G. A. 1996. Parallel evolution of nonfeeding larvae in echinoids. Syst. Biol. 45: 308-322. 


\section{$2 \mathrm{BHL}$ Biodiversity Heritage Library}

Byrne, Maria et al. 2003. "Reproduction and Larval Morphology of Broadcasting and Viviparous Species in the Cryptasterina Species Complex." The Biological bulletin 205, 285-294. https://doi.org/10.2307/1543292.

View This Item Online: $\underline{\text { https://www.biodiversitylibrary.org/item/17303 }}$

DOI: https://doi.org/10.2307/1543292

Permalink: https://www.biodiversitylibrary.org/partpdf/5918

\section{Holding Institution}

MBLWHOI Library

\section{Sponsored by}

MBLWHOI Library

\section{Copyright \& Reuse}

Copyright Status: In copyright. Digitized with the permission of the rights holder.

License: http://creativecommons.org/licenses/by-nc-sa/3.0/

Rights: https://biodiversitylibrary.org/permissions

This document was created from content at the Biodiversity Heritage Library, the world's largest open access digital library for biodiversity literature and archives. Visit BHL at https://www.biodiversitylibrary.org. 